\title{
Czy demokracja to rządy większości wyłonionej w wyborach? ${ }^{1}$
}

\author{
Wojciech Ciszewski \\ Uniwersytet Jagielloński w Krakowie \\ wojciech.ciszewski@uj.edu.pl
}

Otrzymano 7 grudnia 2017, zaakceptowano 21 stycznia 2018, opublikowano 26 kwietnia 2018.

\begin{abstract}
Abstrakt
Przedmiotem artykułu jest krytyka koncepcji demokracji większościowej. W drugiej części tekstu autor wprowadza definicję demokracji większościowej opartą na teorii demokracji minimalnej Josepha Schumpetera. Zgodnie z tą definicją demokracja oznacza rządy większości wyłonionej w cyklicznych wyborach powszechnych. W trzeciej i czwartej części tekstu autor polemizuje z tą koncepcją. Teza artykułu stanowi, że wyłanianie rządzącej większości w drodze wyborów powszechnych nie jest ani koniecznym, ani wystarczającym warunkiem uznania danego ustroju politycznego za demokratyczny. Pojęcie demokracji jest bowiem szersze - obejmuje ono również katalog wartości demokratycznych związanych z kategorią obywatelstwa, szczególnymi warunkami działania politycznego, a także z ograniczeniami władzy w systemie demokratycznym.
\end{abstract}

Słowa kluczowe: demokracja; demokracja większościowa; prawa; wolność; Schumpeter.

\section{Wprowadzenie}

Czy ideę ustroju demokratycznego można sprowadzić do rządów większości wybieranej w drodze cyklicznych wyborów powszechnych? Takie rozumienie demokracji wydaje się dominować w dyskursie medialnym. Jest ono także bardzo popularne w polskiej dyskusji akademickiej (Szymanek, 2005, 2013, s. 24). Zgodnie z tym podejściem, które będę

\footnotetext{
${ }^{1}$ Niniejszy artykuł został opracowany w ramach projektu badawczego pod tytułem Rozum publiczny między faktami a zasadami. Krytyka wizji sprawiedliwości Johna Rawlsa finansowanego ze środków NCN (konkurs Preludium) na podstawie umowy UMO-2013/09/N/HS5/00669. Dziękuję E. Matejkowskiej i R. Michalczakowi za uwagi zgłoszone do wcześniejszych wersji artykułu.
} 
w dalszej części artykułu nazywał „większościowym”, demokrację postrzega się jako system polityczny przyznający władzę polityczną ludowi², który poprzez mechanizm wyborów powszechnych deleguje tę władzę na swoich przedstawicieli. Wybory stanowią w tej perspektywie obligatoryjny element ustroju demokratycznego. Bezpośrednie przywództwo w państwie demokratycznym obejmuje siła polityczna (ugrupowanie albo koalicja ugrupowań politycznych), która uzyskała poparcie większości głosujących. Nadrzędność władzy, jaką dysponuje lud, ma zatem ograniczone znaczenie dla bieżącego realizowania celów politycznych. Sprowadza się ona w zasadzie wyłącznie do możliwości nieprzedłużenia mandatu politycznego w następnych wyborach (ewentualnie - w pewnych okolicznościach - również do obowiązku uwzględniania przez rządzących rozstrzygnięć przyjmowanych w procedurze referendalnej, o ile taką procedurę przewiduje ustrój danego państwa).

W niniejszym artykule twierdzę, że powyższe większościowe rozumienie demokracji jest zaledwie jedną z interpretacji idei demokracji, w moim przekonaniu nieuprawnioną. Ustroju demokratycznego nie należy utożsamiać z rządami większości wyłonionej w wyborach powszechnych. Regularnie odbywające się wybory przedstawicieli politycznych nie stanowią o naturze systemu demokratycznego. Nie są one ani warunkiem koniecznym, ani wystarczającym uznania danego systemu politycznego za demokratyczny.

Powyższą tezę uzasadniam w trzech częściach niniejszego artykułu. W części drugiej omówię szczegółowo, jak rozumiem większościowe ujęcie demokracji. Odwołam się w tym celu do dyskusji filozoficznej, jaka toczy się wokół idei demokracji, w szczególności do tych koncepcji, które w sposób spójny porządkują intuicje związane z podejściem większościowym. W części trzeciej zakwestionuję twierdzenie, że cykliczne wybory powszechne są warunkiem koniecznym uznania jakiegoś systemu politycznego za demokratyczny. Moim zdaniem w ten sposób możemy scharakteryzować również ustrój, który w ogóle nie przewiduje mechanizmu wymiany osób rządzących w drodze wyborów. W części czwartej wykażę natomiast, dlaczego fakt odbywania się cyklicznych wyborów powszechnych w danym systemie politycznym nie jest równoznaczny ze stwierdzeniem, że ten system ma charakter demokratyczny. Innymi słowy, uzasadnię tezę, że instytucja wolnych wyborów nie wyraża istoty systemu demokratycznego.

Warto zaznaczyć, że rozważane w artykule zagadnienie jest niezwykle istotne nie tylko dla dyskusji o naturze demokracji. Rozstrzygnięcie powyższego sporu ma bowiem bezpośrednie przełożenie na poprawność używania kategorii „demokratyczny” w innych kontekstach, a zatem określania choćby decyzji politycznych czy instytucji państwowych jako zgodnych bądź niezgodnych z ideą demokracji. Jeżeli stanowisko, którego bronię w niniejszym artykule, jest słuszne, to dostarcza ono argumentu na rzecz stwierdzenia, że przykładowo - fakt, iż sądy konstytucyjne mogą uchylać decyzje większości parlamentarnej wybranej w wyborach, nie stanowi ograniczenia demokratycznego charakteru danego

\footnotetext{
${ }^{2} \mathrm{~W}$ polskiej tradycji politycznej często używa się w tym kontekście pojęcia „,naród polityczny”. Termin „lud” („lud demokratyczny”) jest jednak w moim przekonaniu bardziej adekwatnym odpowiednikiem greckiego demos, lacińskiego populus i angielskiego the people.
} 
ustroju. Wręcz przeciwnie, uznanie innego rozumienia demokracji niż ujęcie większościowe przemawia za interpretowaniem sądowej kontroli konstytucyjności jako instytucji, która urzeczywistnia istotę systemu demokratycznego.

\section{Koncepcje demokracji większościowej}

W tej części tekstu omówię koncepcje demokracji, które mogą stanowić teoretyczne wsparcie dla podejścia, które wyżej określiłem jako większościowe. W moim przekonaniu warte rozważenia w tym kontekście są przynajmniej dwie teorie dyskutowane w literaturze. Pierwszą z nich jest agregatywne rozumienie demokracji, czerpiące z filozofii politycznej Jeremy’ego Benthama, a drugą - ujęcie minimalistyczne, wyłożone przez Josepha Schumpetera.

\subsection{Demokracja agregatywna}

Agregatywna koncepcja demokracji jest ściśle związana z głoszoną przez Benthama filozofią utylitaryzmu. W pewnym uproszczeniu możemy powiedzieć, że Benthamowski utylitaryzm zakładał, że moralnie słuszne są działania, które prowadzą do maksymalizacji szczęścia rozumianego jako zaspokajanie indywidualnych preferencji (Bentham, 1958). Szczęście ogółu oznacza tutaj sumę zrealizowanych preferencji poszczególnych jednostek (Bentham, 1958, s. 19-20). Powyższa zasada odniesiona do sfery politycznej uzasadniała postulat, że najbardziej pożądanym jest ustrój, który zwiększa stan ogólnej społecznej szczęśliwości, a zatem zapewnia szczęście jak największej grupie osób. Zgodnie z linią argumentacji Benthama najgorszym ustrojem jest tyrania, ponieważ rządy, które sprawuje jednostka, będą zmierzały do zaspokajania preferencji tylko jednej osoby. Najlepszym możliwym ustrojem jest natomiast demokracja, bo umożliwia ona realizację preferencji większości obywateli.

Koncepcja Benthamowska opiera się na kilku założeniach, o których warto wspomnieć. Przede wszystkim zakłada ona, że preferencjom każdej osoby przysługuje dokładnie taka sama wartość. Każdy obywatel dysponuje bowiem równą „siłą” polityczną, to jest pojedynczym głosem wyborczym. Co więcej, na gruncie modelu agregatywnego przyjmuje się pewne szczególne założenia co do racjonalności aktu wyborczego. Zakłada się, że każdy obywatel podejmuje decyzję wyborczą po przeprowadzeniu analizy własnych preferencji (po rozważeniu, jakie posiada preferencje oraz czy ich zaspokojenie leży w jego interesie). Tylko przy przyjęciu, że każdy głosuje zgodnie ze swoimi indywidualnymi i uświadomionymi preferencjami, można uważać wynik głosowania za wiarygodne odzwierciedlenie preferencji występujących w społeczeństwie.

Co istotne, pomimo iż powyższy tok rozumowania można odczytywać jako argument na rzecz bezpośredniego rozstrzygania spraw politycznych przez obywateli, Bentham opowiada się jednoznacznie za instytucją reprezentacji politycznej (Bentham 2002, s. 429-431). 
Argumentuje on, że działalność legislacyjna wymaga specjalistycznej wiedzy oraz szczególnych umiejętności, którymi nie dysponuje znaczna część obywateli. Jego zdaniem rozsądnym rozwiązaniem w tej sytuacji jest przekazanie władzy ustawodawczej przedstawicielom ludu wyłonionym w wyborach powszechnych. Według Benthama mechanizm agregowania preferencji nie zostanie osłabiony przez takie rozwiązanie, ponieważ władze publiczne pochodzące z wyborów będą musiały liczyć się z preferencjami obywateli. Sankcją za działanie niezgodne $\mathrm{z}$ tymi preferencjami jest bowiem nieprzedłużenie mandatu parlamentarnego przy okazji następnych wyborów. Poprzez mechanizm wyborczy każdy obywatel ma możliwość wypowiedzenia się, czy działania reprezentantów politycznych czynią zadość jego indywidualnym preferencjom. A w związku z tym, że reprezentanci polityczni są zainteresowani przedłużeniem swoich kadencji, mają oni powód, aby działać zgodnie z preferencjami większości.

Koncepcja agregatywna nie wytrzymuje jednak krytyki (Dahl, 2012, s. 208-220; Barry, 2003, s. 321-350). Zwrócę uwagę jedynie na kilka kłopotliwych kwestii, które - w moim przekonaniu - skutecznie podważają zasadność kluczowego dla powyższej argumentacji stwierdzenia, że instytucja wyborów stanowi skuteczny mechanizm maksymalizacji szczęścia w wymiarze społecznym.

Po pierwsze, bardzo wątpliwe wydaje się założenie, że każdy obywatel podejmuje decyzję wyborczą wyłącznie w oparciu o swoje indywidualne preferencje i własny interes. Znaczna część elektoratu głosuje, uwzględniając innego typu racje, takie jak postulaty sprawiedliwości społecznej, moralność publiczną albo określone wizje dobra wspólnego (Waldron, 1993, s. 397). Ostateczne rozstrzygnięcie pojedynczego wyborcy nie musi być zgodne z tym, co przysporzyłoby mu najwięcej korzyści. Takie nastawienie w przypadku choćby grupy wyborców podważa jednak możliwość interpretowania wyniku wyborów jako prostego rachunku agregacji preferencji. Po drugie, kłopotliwe wydaje się założenie, że wszyscy obywatele są zdolni do tego, aby w sposób racjonalny ustalić, które z posiadanych przez nich preferencji są zgodne $\mathrm{z}$ ich interesem (Waldron, 1993, s. 96). Z pewnością nie wszyscy podejmują taki pogłębiony namysł przy okazji wyborów, a spośród tych, którzy go podejmują nie wszyscy trafnie rozpoznają, co rzeczywiście leży w ich interesie. Oznacza to, że decyzje wyborcze przynajmniej części osób nie odzwierciedlają ich racjonalnych preferencji. W konsekwencji urzeczywistnianie tych decyzji w praktyce politycznej nie będzie się przyczyniać się do szczęścia ogółu. Po trzecie, źródłem dalszych kłopotów jest przyjmowana przez Benthama zasada, zgodnie z którą preferencjom każdej z osób odpowiada jeden głos w wyborach. Jest to problematyczne przede wszystkim dlatego, że preferencje poszczególnych osób mają różną intensywność oraz odmienny charakter. Rozważana koncepcja zdaje się ignorować ten fakt. Nieuwzględnienie stopnia intensywności preferencji w ogólnym ich rachunku prowadzi ostatecznie do zrównania stanowisk osób, którym bardzo zależy na określonym rozstrzygnięciu sprawy, oraz tych, którzy opowiadają się za jakimś rozwiązaniem, choć nie są do niego przekonani. Demokratyczna agregacja nie bierze także pod uwagę tego, że niektórzy wyborcy kierują się swoimi preferencjami negatywnymi, co oznacza, że głosując, chcą przede wszystkim 
zapobiec zwycięstwu niechcianej opcji politycznej. W związku z tym nie popierają rozwiązania, które najpełniej wyrażałoby ich preferencje, ale opowiadają się za takim, które ma szansę osiągnąć lepszy wynik wyborczy. Wszystkie wymienione wyżej komplikacje sprawiają, że idea agregowania preferencji nie jest wiarygodnym mechanizmem realizacji szczęścia w wymiarze społecznym, co podważa agregatywną wizję demokracji.

\subsection{Demokracja wyborcza ${ }^{3}$}

Na liczne słabości teorii Benthama wskazywał również Joseph Schumpeter. Zaproponowana przez Schumpetera koncepcja demokracji wyborczej miała być odpowiedzią na problemy, w jakie wikła się podejście agregatywne. Przede wszystkim opiera się ona na odmiennym rozumieniu roli, jaką w demokratycznym systemie odgrywa lud. Przypomnijmy, że zgodnie z wizją Benthama obywatele mają określone preferencje i stosownie do nich podejmują decyzje polityczne. Środkiem realizacji tych decyzji jest wybór reprezentantów, którzy następnie urzeczywistniają preferencje większości, prowadząc działalność legislacyjną. Schumpeter zwraca jednak uwagę, że takie postawienie sprawy czyni ów wybór reprezentantów „wtórnym” w stosunku do rozstrzygnięć, które zapadają na poziomie indywidualnym, a ponieważ umocowanie Benthamowskiej zależności między jednostkowymi preferencjami a działaniami reprezentantów politycznych okazuje się bardzo kłopotliwe, Schumpeter proponuje, aby całkowicie przedefiniować tę relację (Schumpeter, 2009, s. 336). Jego zdaniem należy przyjąć, że wybór przedstawicieli jest „pierwotny” w stosunku do rozstrzygnięć politycznych. Demokracja w tej perspektywie nie służy zatem zaspokajaniu preferencji obywateli. Rola tych ostatnich sprowadza się wyłącznie do przyznawania władzy określonej sile politycznej poprzez wybory demokratyczne. Kwestia tego, czy decyzje podejmowane przez reprezentantów politycznych są zgodne z wolą większości wyborców, nie jest w ogóle istotna z perspektywy definicji demokracji.

Demokracja Schumpeterowska jest „rozwiązaniem instytucjonalnym dochodzenia do decyzji politycznych, w którym jednostki uzyskują moc decydowania poprzez walkę konkurencyjną o głosy wyborców” (Schumpeter, 2009, s. 336-337). Zgodnie z tą koncepcją, istotą systemu demokratycznego są cykliczne wybory powszechne, przy okazji których partie polityczne rywalizują o głosy wyborców i przywództwo w państwie. Stosunek partii politycznych do wyborców Schumpeter wielokrotnie porównuje do relacji między producentami a konsumentami dóbr dystrybuowanych na wolnym rynku. Działania kupujących w warunkach rynkowych są ograniczone ofertą przedstawianą przez rywalizujących ze sobą producentów. Konsumenci posiadają swobodę decyzyjną, ale jedynie w granicach, jakie stwarza im rynek. Z kolei producentów nic nie zmusza do tego, aby kierowali się racjonalnymi preferencjami kupujących - interes producentów sprowadza się wyłącznie do tego, aby sprzedać określone dobra. Ten cel może zostać zrealizowany

\footnotetext{
${ }^{3}$ Sformułowanie ,demokracja wyborcza” (electoral democracy) na określenie koncepcji Schumpetera przyjmuję za L. Diamondem. W literaturze koncepcja ta występuje również pod innymi nazwami jako „demokracja minimalna” albo „konkurencyjno-zwrotna teoria demokracji” (Diamond, 1999, s. 8; Sartori, 1998, s. 194).
} 
poprzez wygenerowanie zapotrzebowania, a więc poprzez odpowiednie ukształtowanie upodobań konsumentów. Racjonalny interes tych ostatnich ma w tej perspektywie, co najwyżej, drugorzędne znaczenie.

Powyższa koncepcja jest warta uwagi między innymi dlatego, że Schumpeter wykazuje daleko idącą konsekwencję w swojej argumentacji i otwarcie akceptuje wnioski, do których prowadzi przyjęcie wyborczego modelu demokracji. Myślę, że warto wspomnieć w szczególności o dwóch tego rodzaju konkluzjach.

Po pierwsze, Schumpeter podkreśla, że instytucje demokracji wyborczej zapewniają obywatelom wpływ na wybór przywódców politycznych - nie dają jednak żadnej możliwości ich kontroli. Rola obywateli wyczerpuje się bowiem w podejmowanym raz na jakiś czas akcie głosowania. Rzecz jasna, Schumpeter ma świadomość tego, że w rzeczywistej polityce często dochodzi do istotnych zmian nastrojów społecznych, które „bezpośrednio powodują upadek rządu czy konkretnego ministra albo wymuszają pewien kierunek działania" (Schumpeter, 2009, s. 340). Jednak w związku z tym, że demokracja nie jest niczym więcej niż mechanizmem wyłaniania przywództwa politycznego poprzez wybory, inne niż głosowanie próby wpływania na rządzących Schumpeter określa jako „sprzeczne z duchem metody demokratycznej” (Schumpeter, 2009, s. 340).

Po drugie, Schumpeter wskazuje jednoznacznie, że nie istnieje żaden konieczny związek między demokracją większościową a realizacją woli ludu. Jak sam pisze, ,jest oczywiste, że wola większości jest tylko właśnie wolą większości, dlatego nie może być utożsamiana z wolą ludu”. Natomiast decyzje podejmowane przez rządzącą większość ,przeważnie nie będą jej [woli ludu - przyp. autor] wyrażać, lecz raczej ją wypaczą” (Schumpeter 2009, s. 340). Schumpeter zauważa, w związku z tym, że wola ludu stanowi swoistą ,mozaikę”, jej realizacja nakazywałaby raczej dokonanie podziału władzy w państwie między partie polityczne proporcjonalnie do społecznego poparcia, jakim dysponują. Koncepcja demokracji wyborczej nie postuluje jednak takiego rozwiązania. Schumpeter pisze wprost, że na gruncie jego koncepcji nie jest wymagane nawet istnienie opozycji parlamentarnej (Schumpeter, 2009, s. 340-341).

Możemy zatem stwierdzić, że demokracja wyborcza - rozumiana jako rządy większości wyłonionej w wyborach - stanowi spójną propozycję. Teoria Schumpetera wykazuje jednak poważne słabości, gdy przychodzi do rozważenia jej uzasadnienia. Jest to kwestia o tyle istotna, że Schumpeter broni swojej propozycji jako właściwej koncepcji demokracji, a zatem możemy oczekiwać, że wykaże on jej wyższość nad konkurencyjnymi ujęciami ustroju demokratycznego. Pod tym względem rozważania Schumpetera rozczarowują. W jego analizach możemy doszukać się dwóch strategii argumentowania na rzecz słuszności koncepcji demokracji wyborczej.

\footnotetext{
${ }^{4}$ Obie te strategie argumentacyjne uzasadniają wyższość koncepcji Schumpetera nad koncepcją, którą określa on jako klasyczną doktrynę demokracji.
} 
Pierwszy argument głosi, że koncepcja demokracji wyborczej dostarcza efektywnego kryterium rozróżnienia systemów demokratycznych od niedemokratycznych. Zdaniem Schumpetera definicja agregatywna nie sprawdza się na tym polu - polegając na tej ostatniej, nie sposób stwierdzić, czy dany system polityczny faktycznie maksymalizuje szczęście w wymiarze społecznym (a w efekcie nie sposób stwierdzić, czy określony ustrój jest rzeczywiście demokratyczny; Schumpeter, 2009, s. 337). Na tym tle kwestia funkcjonowania cyklicznych wyborów powszechnych jawi się jako klarowne kryterium demokratycznego charakteru danego ustroju. Warto zaznaczyć, że w perspektywie Schumpetera demokracja nie jest ideałem możliwym do zrealizowania w większym bądź mniejszym stopniu - warunek uznania danego systemu za demokratyczny w konkretnym przypadku albo jest, albo nie jest spełniony.

Drugi argument stanowi, że rozważana koncepcja jest spójna z naszymi intuicjami dotyczącymi natury systemu demokratycznego. Ujęcie demokracji odwołujące się do wyborów - w opinii Schumpetera - honoruje ,wiele z tego, co zwolennicy metody demokratycznej tak naprawdę przez nią rozumieją" (Schumpeter, 2009, s. 336). Autor omawianej koncepcji wskazuje przy tym na realizm swojego podejścia, podkreślając, że jest ono „bliższe życiu”, co odróżnia je od „moralistycznego” nastawienia koncepcji Benthamowskiej. Stwierdza on, że definicja demokracji wyborczej koncentruje się na czynnikach, które są istotne z perspektywy teorii politycznej, w szczególności na kwestii przywództwa politycznego. Jednocześnie Schumpeter zaznacza, że preferowana przez niego definicja pozwala na określenie w sposób wiarygodny relacji metody demokratycznej do innych ważnych kategorii politycznych, takich jak wola ludu lub wolność osobista ${ }^{5}$. Argumentacja Schumpetera przywodzi zatem na myśl Rawlsowską metodę refleksyjnej równowagi, która polega na konstruowaniu teorii w oparciu o posiadane przez nas rozważne sądy oraz intuicje. Stosowania tej metody ma na celu doprowadzenie do sytuacji spójności w obrębie samej teorii, to jest do stanu, w którym składające się na nią sądy będą się wzajemnie wpierać (Rawls, 2009, s. 52-53, 90-91).

Pierwszy z przytoczonych wyżej argumentów trudno w ogóle uznać za uzasadnienie demokracji wyborczej. To, że koncepcja Schumpetera dostarcza jasnego kryterium odróżnienia systemów demokratycznych od niedemokratycznych, nie jest okolicznością, która czyniłaby ją w większym stopniu wiarygodną niż wizje konkurencyjne. Klarowność takiego kryterium ma, jak się wydaje, jedynie drugorzędne znaczenie w stosunku do jego trafności - do tego, czy rozważana definicja poprawnie identyfikuje dany ustrój jako demokratyczny. Gdybyśmy nie byli ograniczeni wymogiem trafności, to bez trudu moglibyśmy

\footnotetext{
${ }^{5} \mathrm{O}$ relacji demokracji wyborczej do pojęcia woli ludu pisałem wyżej. Jeśli zaś chodzi o stosunek zasady demokracji wyborczej do idei wolności osobistej, to Schumpeter twierdzi, że ma on charakter przygodny, to znaczy, że generalnie systemy demokratyczne przyznają szerszy zakres wolności osobistej obywatelom niż systemy niedemokratyczne, ale nie ma w tym przypadku żadnej konieczności i możliwe jest także, aby to system niedemokratyczny realizował w większym stopniu zasadę wolności. Warto dodać, że Schumpeter w swoich rozważaniach bierze pod uwagę negatywne rozumienie wolności.
} 
sformułować jeszcze prostszy probierz demokratyczności ustrojów niż ten Schumpeterowski (na przykład za taki probierz moglibyśmy uznać funkcjonowanie w danym systemie instytucji parlamentu ${ }^{6}$ ). Kluczowe jest zatem to, czy określona definicja oferuje właściwe warunki rozpoznania systemu demokratycznego, a nie to, czy są one łatwe w stosowaniu.

W związku ze słabością pierwszego argumentu ciężar uzasadnienia poprawności definicji Schumpetera zdaje się spoczywać na drugim z nich, to jest na przekonaniu o zgodności twierdzeń rozważanej koncepcji z naszymi intuicjami i rozważnymi sądami odnośnie do natury demokracji. Jeżeli definicja Schumpeterowska trafnie identyfikuje to, co „zwolennicy metody demokratycznej” uznają za istotowy element demokracji, to z pewnością stanowi to jakąś rację na rzecz przyjęcia tej definicji. Aby umocować taki argument, należy jednak szczegółowo rozważyć, czy idea demokracji wyborczej jest rzeczywiście spójna z naszymi intuicjami i rozważnymi sądami. Moja odpowiedź w tej kwestii jest negatywna, co postaram się wykazać w dalszej części tekstu.

\section{Zasada rządów większości wyłonionej w wyborach nie jest warunkiem koniecznym uznania danego systemu za demokratyczny}

W następnych dwóch częściach artykułu dokonam krytyki idei demokracji większościowej. Głównym przedmiotem mojej polemiki będzie koncepcja Schumpetera, ponieważ uważam, że w sposób spójny i sugestywny wyraża ona tę ideę. Jak wskazałem powyżej, zgodnie z definicją Schumpetera demokracja stanowi system polityczny, w którym rządy sprawuje większość wyłaniana w cyklicznych wyborach powszechnych. W tej części tekstu uzasadnię tezę głoszącą, że wybory reprezentantów politycznych nie są warunkiem koniecznym uznania danego ustroju za demokratyczny. W moim przekonaniu system demokratyczny nie wymaga w ogóle funkcjonowania cyklicznych wyborów powszechnych.

Pierwszy argument na rzecz powyższej tezy wydaje się dość oczywisty - za demokratyczny może uchodzić nie tylko ustrój państwowy, w którym regularnie odbywają się wybory przedstawicieli politycznych, ale również taki, w którym nie istnieje żadna forma reprezentacji politycznej, a obywatele sprawują władzę bezpośrednio. W takim systemie nie funkcjonowałby zatem mechanizm wyborów. Decyzje polityczne byłyby podejmowane przez obywateli w drodze głosowania lub rozbudowanego procesu deliberacyjnego ${ }^{7}$. Ponieważ argumentacja Schumpetera sugeruje, że wszyscy posiadamy zbliżone intuicje odnośnie do natury ustroju demokratycznego, warto zaznaczyć, że przez znaczną część

\footnotetext{
${ }^{6}$ Kryterium Schumpeterowskie zastosowane do oceny demokratycznego charakteru konkretnego ustroju może rodzić całą serię pytań, między innymi o to, czy w danym systemie politycznym wybory nie odbywają się zbyt rzadko, czy są rzeczywiście wolnymi wyborami, czy spełniona jest przesłanka powszechności. Wydaje się, że kryterium istnienia parlamentu w danym systemie byłoby jeszcze łatwiejsze do zastosowania.

${ }^{7}$ Między innymi koncepcja demokracji partycypacyjnej Barbera (2003) opiera się na odrzuceniu idei reprezentacji politycznej (w tym także zasady rządów większości wyłonionej w wyborach). Zdaniem Barbera rządy przedstawicieli politycznych prowadzą do wykształcenia niewłaściwych postaw wśród obywateli, a także wyobcowują obywateli z procesu politycznego.
} 
historii ludzkości ideę demokracji utożsamiano właśnie z systemem, który dzisiaj określilibyśmy jako demokrację bezpośrednią. Między innymi James Madison w Federaliście posługiwał się rozróżnieniem demokracji i republiki (Hamilton et al., 2015, s. 111; Dahl, 2012, s. 41-50), a główne kryterium tego rozróżnienia stanowiła możliwość delegowania władzy na przedstawicieli politycznych w drodze wolnych wyborów - takie rozwiązanie uznawano bowiem za charakterystyczne dla systemów republikańskich, a jednocześnie za obce demokracjom. Madison łączył zatem ustrój demokratyczny z zupełnie innymi rozwiązaniami instytucjonalnymi niż Schumpeter.

W stosunku do koncepcji demokracji opierającej się na bezpośrednich rządach obywateli można oczywiście formułować wiele zarzutów. Szczególnie popularna jest krytyka wskazująca na niefunkcjonalność takiego rozwiązania we współczesnych realiach politycznych. Powyższy problem sytuuje się jednak poza zakresem rozważań niniejszego artykułu. Argument, którego bronię w tej części tekstu, głosi jedynie, że ustrój polityczny oparty na mechanizmie demokracji bezpośredniej, w którym nie występowałyby wybory powszechne, mógłby zostać uznany za ustrój o charakterze demokratycznym.

Wspomniany zarzut niefunkcjonalności w żaden sposób nie godzi natomiast w drugi $\mathrm{z}$ argumentów przeciwko demokracji wyborczej. Być może, w związku z powyższym, stanowi on poważniejsze wyzwanie dla koncepcji Schumpeterowskiej. Argument ten głosi mianowicie, że za demokratyczny możemy uznać system przyznający władzę polityczną reprezentantom ludu, którzy nie są wybierani w regularnie organizowanych wyborach powszechnych. Tego rodzaju ustrój mógłby się opierać się na tak zwanej reprezentacji statystycznej i wymagałby wyłaniania przedstawicieli politycznych w drodze losowania.

Warto w tym kontekście wspomnieć, że w literaturze wyróżnia się dwie konkurencyjne zasady reprezentacji w instytucjach przedstawicielskich (Pettit, 2012, s. 195-208; Skinner, 2005, s. 155-184; Saward, 2006). Pierwsza z nich przyjmuje, że skład personalny tego rodzaju instytucji powinien odzwierciedlać zróżnicowanie danego społeczeństwa. Zgodnie z tą perspektywą w organie przedstawicielskim powinni być obecni reprezentanci wszystkich najważniejszych grup społecznych, a ich liczba powinna być proporcjonalna do wielkości danej grupy. Dobrany w ten sposób skład instytucji stanowi niejako społeczeństwo w mikroskali. Kategorią reprezentacji w podobnym sensie posługujemy się, gdy mówimy, że dana opinia jest reprezentatywna dla danej grupy bądź społeczności. Philip Pettit określa tę koncepcję mianem reprezentacji statystycznej (Pettit, 2012, s. 196-197). Konkurencyjne podejście zakłada, że przedstawiciele polityczni podejmują działania w imieniu społeczności i są odpowiedzialni przed społecznością ujmowaną jako pewna całość. Ten rodzaj reprezentacji Pettit nazywa responsywnym. Według niego idea reprezentacji responsywnej przywodzi na myśl relację między pełnomocnikiem prawnym a jego klientem (Pettit, 2012, s. 197-200).

Pettit podkreśla, że każdej z wymienionych zasad reprezentacji odpowiada odmienny mechanizm wyłaniania przedstawicieli politycznych. Zasada reprezentacji responsywnej opiera się na funkcjonowaniu wyborów powszechnych. Na jej gruncie to właśnie wybory czynią członków ciał przedstawicielskich odpowiedzialnymi przed ludem i zmuszają ich 
do zabiegania o poparcie obywateli. Z perspektywy reprezentacji statystycznej taki mechanizm doboru przedstawicieli ma jednak istotne wady. Po pierwsze, nie gwarantuje on, że skład ciała przedstawicielskiego będzie odzwierciedlał zróżnicowanie wewnętrzne danego społeczeństwa. Po drugie, przyczynia się do powstania swoistej klasy zawodowych przedstawicieli - polityków, którzy posiadają własne, to jest grupowe, interesy i cele. Konsekwencją wyodrębnienia się takiej klasy społecznej jest jej odseparowanie od spraw i potrzeb ludu. Z uwagi na te słabości zwolennicy koncepcji reprezentacji statystycznej opowiadają się za wyłanianiem składu instytucji przedstawicielskich w drodze losowania reprezentantów poszczególnych grup społecznych. Formuła losowania zapewnia reprezentatywność ciał przedstawicielskich. Należy przy tym podkreślić, że tego rodzaju mechanizm doboru składu instytucji politycznych funkcjonował w wielu historycznych demokracjach. Najbardziej znanego przykładu dostarcza demokracja ateńska, gdzie poprzez losowanie wyłaniano, między innymi, członków Rady Pięciuset. Wydaje się zatem, że nie ma żadnego powodu, aby taki sposób wyłaniania reprezentacji uznawać za niezgodny z naturą demokracji.

Możliwość oparcia systemu demokratycznego bądź na bezpośrednim udziale obywateli we władzy, bądź na idei reprezentacji statystycznej i obsadzaniu stanowisk w wyniku losowania, przeczą jednak twierdzeniu, że demokracja to rządy większości wyłonionej w drodze wyborów powszechnych. Do miana demokratycznych mogą bowiem aspirować również systemy polityczne, które nie przewidują wyboru przedstawicieli politycznych poprzez mechanizm wyborów.

\section{Zasada rządów większości wyłonionej w wyborach nie jest warunkiem wystarczającym uznania danego systemu za demokratyczny}

W tej części artykułu wskażę na poważniejszą ułomność koncepcji demokracji wyborczej. Będę argumentował, że wyłanianie reprezentantów politycznych w drodze cyklicznych wyborów powszechnych nie jest warunkiem wystarczającym uznania danego ustroju za demokratyczny. Opierając się wyłącznie na naszych intuicjach i rozważnych sądach odnośnie do natury demokracji, możemy stwierdzić, że ustrój demokratyczny to coś więcej niż określona procedura legitymizowania władz publicznych. Na rzecz powyższej tezy przemawiają, w moim przekonaniu, co najmniej cztery argumenty.

Po pierwsze, pojęcie demokracji odnosi się nie tylko do sposobu wyboru władz, ale obejmuje ono również pewien szczególny - właściwy demokracji - katalog uprawnień politycznych. Słuszność tego twierdzenia postaram się uzasadnić w dwóch krokach argumentacyjnych. Pierwszy z nich sprowadza się do przywołania dość oczywistej tezy, że system demokratyczny nie mógłby istnieć bez obywateli demokratycznych. Omawiany ustrój nadaje osobom, które żyją pod jego rządami, pewien szczególny status polityczny - status obywatelski. Innymi słowy, nie ma systemu demokratycznego bez obywateli demokratycznych. 
Drugi krok argumentacji wymaga odpowiedzi na pytanie, co czyni szczególnym status obywateli demokratycznych. Mając na względzie, że na gruncie teorii polityki toczą się spory co do treści idei obywatelstwa, warto zauważyć, że nawet wśród spierających się teoretyków panuje konsensus, że status obywatelski zapewnia osobom, które go posiadają fundamentalną wolność i równość (Kymlicka, 2009, s. 347-396). Z powyższego wynika, że zakres swobód osobistych oraz możliwości działania politycznego, jaki posiada jednostka dysponująca statusem obywatelskim, powinien uprawniać nas do uznania tej jednostki za osobę wolną. Status obywatelski nakłada zatem na rząd demokratyczny obowiązek respektowania katalogu podstawowych uprawnień, na który składają się, między innymi, wolność sumienia, wolność słowa czy prawo do partycypacji politycznej. Zgodnie z zasadą równości statusu każdy z obywateli powinien dysponować takim samym katalogiem praw. Wydaje się, że przy braku któregokolwiek ze wspomnianych uprawnień $\mathrm{w}$ danym systemie politycznym trudno byłoby nam uznać poddanych w tym systemie za wolnych obywateli, a sam system określić mianem demokratycznego.

Po drugie, pojęcie demokracji obejmuje również pewne szczególne warunki działania politycznego. Na ten aspekt ustroju demokratycznego zwraca uwagę między innymi Ronald Dworkin. Jego zdaniem honorowanie podstawowych wartości (szczególnie wolności) demokratycznych stanowi warunek legitymacji rozstrzygnięć politycznych (Dworkin, 1986, s. 17). To, że dana decyzja została podjęta przez wyłonioną w wyborach większość, nie gwarantuje, że decyzja ta ma demokratyczny charakter. Odpowiednia legitymacja rozstrzygnięć zależy bowiem także od okoliczności stanowiących swego rodzaju „tło” dokonywanych ustaleń.

Powyższy tok rozumowania Dworkin ilustruje następującym przykładem. Załóżmy, że w danym państwie wprowadzono zakaz krytyki projektów legislacyjnych zgłaszanych przez rządzącą większość. Niemożliwość zgłaszania zastrzeżeń dotyczy wszystkich: opozycji parlamentarnej i pozaparlamentarnej, a także komentatorów, ekspertów i przedstawicieli organizacji społecznych. Za formułowanie jakichkolwiek ocen negatywnych pod adresem projektów legislacyjnych grozi kara pozbawienia wolności. W takich warunkach niemożliwe staje się prowadzenie rzetelnej i uczciwej debaty publicznej. Rządzący, rzecz jasna, przegłosowują swoje projekty, ponieważ dysponują większością w parlamencie wszystkie ustawy są zatem przyjmowane z poszanowaniem reguły większości. Powstaje jednak pytanie, czy prawo procedowane w takich warunkach, ewidentnie urągających zasadzie wolności słowa, możemy określić mianem demokratycznego. Jeżeli demokracja oznacza wyłącznie rządy większości, to odpowiedź powinna być pozytywna. Takie stanowisko jest jednak nieprzekonujące. Wydaje się, że nasze rozumienie demokracji jako ustroju politycznego obejmuje coś więcej niż tylko sposób przekazywania władzy w państwie. Przykład Dworkina unaocznia, że demokracja to również określone warunki działania politycznego, które determinują legitymację rozstrzygnięć politycznych. Zagwarantowanie kluczowych swobód demokratycznych traktujemy bowiem jako czynnik decydujący o akceptowalności decyzji podejmowanych przez większość. 
Po trzecie, demokracja to także określone mechanizmy ograniczające działanie władz publicznych. Pojęcie demokracji często przeciwstawiane jest pojęciom absolutyzmu czy autorytaryzmu (Sartori, 1998, s. 228-264). Również odwołując się do perspektywy historycznej, możemy powiedzieć, że źródłem postulatów demokratyzacji ustroju politycznego był sprzeciw wobec absolutyzmu władzy. W tym kontekście uprawnionym wydaje się stwierdzenie, że demokracja jest systemem, który istotowo różni się od absolutyzmu. Sam absolutyzm można natomiast zdefiniować jako system polityczny, w którym przywódcom (osobie albo grupie osób) przysługuje nieograniczona władza. Rządzący mają w szczególności pełną swobodę, jeśli chodzi o tworzenie prawa. Nie istnieją ustrojowe ograniczenia zakresu ich władzy.

Zwróćmy uwagę, że demokracja wyborcza nie różni się w istotny sposób od tak rozumianego absolutyzmu. Definicja Schumpetera zakłada, co prawda, że władzę sprawuje pewna grupa (przedstawiciele większości społecznej), a także że jej legitymacja do rządzenia jest ograniczona w czasie (przez mechanizm wymiany władzy w drodze wyborów), ale żadna z tych okoliczności nie stanowi o odmienności istotowej demokracji od absolutyzmu. Kluczowe jest w szczególności to, że koncepcja demokracji wyborczej nie nakłada żadnych ograniczeń na działania władz politycznych w czasie trwania ich kadencji. Innymi słowy, koncepcja ta dopuszcza, aby między poszczególnymi wyborami wyłoniona większość posiadała pełną, to jest absolutną, swobodę w zakresie sprawowania władzy.

W moim przekonaniu, powyższa konkluzja jest kłopotliwa dla koncepcji Schumpetera. Jeśli zgodzimy się, że demokracja to system z natury odmienny od absolutyzmu, to nie sposób utrzymać większościowego rozumienia demokracji. Aby spełnić ten „wymóg odmienności”, koncepcja demokracji musi wskazywać zasady i mechanizmy uniemożliwiające sprawowanie absolutystycznych rządów. Warto zauważyć, że praktyka funkcjonowania demokracji zna wiele instytucji pełniących taką rolę. Do najważniejszych należą: trójpodział władzy, katalog praw i wolności jednostkowych, zasada rządów prawa, zasada niezależności władzy sądowniczej oraz sądownictwo konstytucyjne. To właśnie obecność powyższych mechanizmów ograniczających władzę, a nie sposób wyłaniania rządzących, przesądza o odmienności demokracji od absolutyzmu.

Po czwarte, demokracja to ustrój, który uznajemy za godny urzeczywistnienia. Wydaje się, że taka intuicja towarzyszy zdecydowanej większości wypowiedzi na temat demokracji - że jest to system w istotnym sensie lepszy od konkurencyjnych rozwiązań politycznych (Saward, 2008, s. 29, 42-47). Powstaje, oczywiście, pytanie, co czyni ustrój demokratyczny godnym urzeczywistnienia w powyższym sensie. Najczęściej wskazuje się, że na jego rzecz przemawiają pewne fundamentalne wartości polityczne, takie jak choćby idea wolności. Uwaga ta jest o tyle istotna, że koncepcja demokracji większościowej wykazuje bardzo wiele wad ustrojowych, które mogą podważać fundamentalne wartości, ze względu na które cenimy demokrację. Najważniejszą słabością tego rodzaju jest zagrożenie tyranią większości, a zatem możliwość zaistnienia sytuacji, gdy wybrana w wyborach większość, intencjonalnie bądź nieintencjonalnie, dominuje na mniejszością 
społeczną, ograniczając swobody osób należących do tej mniejszości (może się to odbywać poprzez odebranie części praw albo narzucanie własnych preferencji; Pettit, 2012, s. 211-215; Sartori, 1998, s. 171-175).

Obrońca demokracji większościowej może jednak potraktować słabości ustrojowe, takie jak tyrania większości, jako zagrożenia, które są wpisane w naturę demokracji. Może on argumentować, że demokracja, pomimo swoich zalet, nie jest systemem doskonałym, a ryzyko zdominowania mniejszości przez większość jest właśnie jedną z tego rodzaju ułomności. Takie postawienie sprawy nie jest jednak przekonujące między innymi dlatego, że w naszych rozważaniach politycznych staramy się utrzymać rozumienie demokracji jako ustroju politycznego, który jest godny realizacji. Jeżeli zgodzimy się, że w pojęcie demokracji wpisane są tak poważne wady ustrojowe, to nasze powody, by ją cenić, zostają w istotny sposób osłabione - w takiej sytuacji nie jest jasne, co czyni demokrację bardziej wartościową od konkurencyjnych ustrojów (na przykład od tyranii rządzonej przez łaskawego tyrana).

Innymi słowy, skoro demokracja większościowa nie zabezpiecza w odpowiedni sposób wartości, które są cenne z punktu widzenia obywateli demokratycznych, to przestaje ona być czymś godnym pożądania. W związku z powyższym, jeżeli chcemy ocalić pojęcie demokracji jako ustroju wartego urzeczywistnienia, to powinniśmy przyjąć takie jej rozumienie, które będzie odporne na rzeczone wady konstrukcyjne. Demokracja jest ideałem, który kształtujemy, realizujemy i doskonalimy. Dlatego, w moim przekonaniu, nie ma powodu, by utrzymywać, że właściwym rozumieniem tego ustroju jest to, które czyni go podatnym na tak poważne zarzuty. Wobec powyższego powinniśmy uznać, że dominacja większości nad mniejszością nie harmonizuje z istotą demokracji. Większość w systemie demokratycznym ma obowiązek honorować równą wolność wszystkich obywateli. Obowiązek ten nie jest jakimś zewnętrznym ograniczeniem, jakie na system demokratyczny nakłada kultura polityczna danego społeczeństwa, ale wyraża on głęboką naturę tego systemu. Dopiero demokracja rozumiana jako system zabezpieczający wolność każdego z obywateli jest czymś wartym urzeczywistnienia w praktyce politycznej.

\section{Podsumowanie}

Podsumowując rozważania w niniejszym artykule, należy stwierdzić, że utożsamienie demokracji z zasadą rządów większości wyłonionej w wyborach stanowi nieadekwatną interpretację tej idei. Przedmiotem mojej polemiki była interpretacja demokracji większościowej przedstawiona przez Schumpetera oraz argument na jej rzecz odwołujący się do intuicji związanych z pojęciem demokracji. Jak wykazałem w trzeciej części tekstu, wybór przywództwa politycznego w cyklicznych wyborach powszechnych nie jest koniecznym warunkiem uznania danego systemu za demokratyczny. Ustrój demokratyczny może bowiem nie przewidywać w ogóle instytucjonalnej reprezentacji politycznej (system demokracji bezpośredniej lub partycypacyjnej) albo wprowadzać reprezentację, która nie będzie 
wyłaniana w drodze wyborów (system reprezentacji statystycznej). W czwartej części tekstu uzasadniłem tezę, że ustrój demokratyczny to coś więcej niż treści, które przyjmuje idea demokracji większościowej. Rekonstruując pojęcie demokracji, nie możemy pominąć znaczenia fundamentalnych wartości demokratycznych związanych z kategorią obywatelstwa, szczególnymi warunkami działania politycznego, a także z ograniczeniami władzy w systemie demokratycznym.

\section{Bibliografia}

Barber, B. (2003). Strong democracy: Participatory politics for a new age. Berkeley: University of California Press.

Barry, B. (2003). Is democracy special. W: T. Christiano (red.), Philosophy and democracy: An anthology. Oxford, UK: Oxford University Press.

Bentham, J. (1958). Wprowadzenie do zasad moralności i prawodawstwa. Warszawa: PWN.

Bentham, J. (2002). Rights, representation, and reform: Nonsense upon stilts and other writings on the French Revolution. Oxford, UK: Oxford University Press.

Dahl, R. A. (2012). Demokracja i jej krytycy. Warszawa: Aletheia.

Diamond, L. (1999). Developing democracy: Toward consolidation. Baltimore, MA: Johns Hopkins University Press.

Dworkin, R. (1986). Freedom's law: The moral reading of the American Constitution, Cambridge, MA: Harvard University Press.

Hamilton, A., Madison, J, Jay, J. (2015). The federalist papers, Mineola, NY: Dover Publications.

Kymlicka, W. (2009). Współczesna filozofia polityczna. Warszawa: Aletheia.

Pettit, P. (2012). On the people's terms: A republican theory and model of democracy. Cambridge, UK: Cambridge University Press.

Rawls, J. (2009). Teoria sprawiedliwości. Warszawa: PWN.

Sartori, G. (1998). Teoria demokracji. Warszawa: PWN.

Saward, M. (2006). The representative claim. Contemporary Political Theory, 5(3), 297-318.

Saward, M. (2008). Demokracja. Warszawa: Wydawnictwo Sic!

Skinner, Q. (2005). Hobbes on representation. European Journal of Philosophy, 13(2), 155-184.

Szymanek, J. (2005). Wspótczesne rozumienie pojęcia reprezentacji politycznej (zarys problemu). Ruch Prawniczy, Ekonomiczny i Socjologiczny, 67(2), 223-237.

Szymanek, J. (2013). Reprezentacja i mandat parlamentarny. Warszawa: Wydawnictwo Sejmowe.

Waldron, J. (1993). Liberal rights: Collected papers 1981-1991. Cambridge, UK: Cambridge University Press. 


\title{
Is Democracy the Rule of Majority Chosen in Elections?
}

\begin{abstract}
The paper critically examines the conception of majoritarian democracy. In the second part of the text, the author introduces the definition of majoritarian democracy based on the Joseph Schumpeter's theory of minimal democracy. The thesis of the paper is that electing the government by universal suffrage is neither necessary nor sufficient as a condition for a democratic regime. The concept of democracy is broader, including the catalogue of democratic values connected with the concept of democratic citizenship, special circumstances of political action and the limitation of government powers.
\end{abstract}

Keywords: democracy; majoritarian democracy; rights; freedom; Schumpeter. 